УДК 82I.I6І.І

ББК $83.3(2 \mathrm{Poc}=\mathrm{Pyc}) 6+$ $76.17(2 \mathrm{Poc}=\mathrm{Pyc})+63.3(2) 612$
ИЗДАТЕЛЬСКИЙ ПРОЕКТ М. ГОРЬКОГО «ИСТОРИЯ ГРАЖДАНСКОЙ ВОЙНЫ»: ПО МАТЕРИАЛАМ АРХИВА А.М. ГОРЬКОГО (ИМЛИ РАН) И РГАСПИ

\author{
(C) 2017 г. О.В. Быстрова \\ Институт мировой литературы \\ им. А.М. Горького Российской академии наук, \\ Москва, Россия \\ Дата поступления статьи: 2I сентября 2017 г. \\ Дата публикации: 25 декабря 2017 г. \\ DOI: IO.22455/2500-4247-20I7-2-4-378-393
}

Аннотация: Статья посвящена истории замысла М. Горького - создание книгоиздательской серии «История Гражданской войны». Публикация и анализ писем Горького из Архива А.М. Горького (ИМЛИ РАН) адресатам І929-І930 гг. позволяют сделать вывод, что замысел серии сформировался в самом начале г928 г. В статье рассматривается процесс формирования книгоиздательской серии, в ходе которого по указанию ЦК ВКП(б) к собиранию документов и воспоминаний участников Гражданской войны были широко привлечены партийные, советские и военные работники во всех республиках, краях и областях. По замыслу Горького, изложение томов «Истории гражданской войны» должно быть популярным и доступным для массового читателя. Для этой цели должны привлекаться к обработке документального материала талантливые советские писатели, которые принимали участие в Гражданской войне. К рекомендациям Горького прислушивались и при создании редакторского ядра серии. Постановлением ЦК ВКП(б) от 3І июля І93І г. была создана редколлегия Главной редакции, Исторической и Художественной редакций серии, в состав всех трех вошел Горький. Под его руководством Секретариат Главной редакции «ИГВ» разработал инструктивные указания, призванные дать ориентиры в широком круге проблем исследования, а также вооружить методикой обработки материалов. Другим важным вопросом, который исследуется в статье, является уточнение объема серии. И если предварительный расчет сводился к 6 томам по 25 листов, то в процессе работы над серией редакция остановилась на I5 томах. Публикуемые письма Горького из коллекции РГАСПИ позволяют оценить огромный объем работы, которую вел писатель в процессе подготовки первого тома к изданию. Если вышедший в 1935 г. первый том серии «История гражданской войны» отражал концепцию, заложенную Горьким, то последующие четыре тома вышли после смерти писателя и являли собой иную концепцию по сравнению с заявленной. Тем не менее замысел Горького был исполнен, и «История гражданской войны» была представлена обществу.

Ключевые слова: М. Горький, «История гражданской войны», эпистолярий, редактура, книгоиздательская серия.

Информация об авторе: Ольга Васильевна Быстрова - кандидат филологических наук, доцент, старший научный сотрудник, Институт мировой литературы имени А.М. Горького Российской академии наук, ул. Поварская, д. 25 а, І2Іо69 г. Москва, Россия.

E-mail: bystrova63@mail.ru 


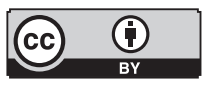

This is an open access article distributed under the Creative Commons Attribution 4.0 International (CC BY 4.0)

\section{GORKY'S EDITORIAL PROJECT \\ THE HISTORY OF THE CIVIL WAR: ON THE MATERIALS OF THE A.M. GORKY (IWL RAS) AND RGASPI ARCHIVES}

\author{
(C) 20I7. O.V. Bystrova \\ A.M. Gorky Institute of World Literature \\ of the Russian Academy of Sciences, Moscow, Russia \\ Received: September 2I, 20I7 \\ Date of publication: December 25, 2017
}

Abstract: The article focuses on the history of Maksim Gorky's design - the publication of the History of the Civil War volumes. The analysis of Gorky's correspondence (1929-1930) from the A.M. Gorky archives (IWL RAS) reveals that the idea of the collection emerged at the beginning of 1928 . In the course of the preparatory work, the Central Committee of the CPSU(b) obliged Communist party officials, Soviet and military functionaries in all Soviet republics and regions to collect documents and memories of the Civil War, to write and review materials for the collection. Gorky conceived the volumes of The History of the Civil War to be popular and accessible to the average reader. For this purpose, he considered inviting talented Soviet authors who took part in the Civil War. Gorky's recommendations were taken into account while forming the Editorial Board. The CC of the CPSU(b) on July 3I, I93I established the Editorial Board (comprised of Chief, Historical and Artistic Boards) that Gorky also joined. Under his guidance, the Secretariat of the Chief Editorial Board issued instructions that were intended to direct a wide range of research subjects and provide researchers with methodology. Gorky's letters from the RGASPI collection give us idea of the huge amount of work done by the writer in the process of preparing the first volume for publication. If the first, I935 volume reflects Gorky's vision and concept of the collection, the subsequent 4 volumes published after his death departed from the original design. Despite this and the fact that only 5 volumes out of I 5 were issued, we can state that Gorky's design was realized and that the History of the Civil War still remains an authoritative book in the field.

Keywords: Maxim Gorky, History of the Civil War, correspondence, editing, publishing series.

Information about the author: Olga V. Bystrova, PhD in Philology, Senior Researcher, A.M. Gorky Institute of World Literature of the Russian Academy of Sciences, Povarskaya 25 a, I21069 Moscow, Russia.

E-mail: bystrova63@mail.ru 
29 июля 193І г. Горьким была закончена работа над статьей «Участникам Гражданской войны», которая была опубликована в центральной прессе [см.: 3, 4] одновременно с Постановлением ЦК ВКП(б) «Об издании “Истории Гражданской войны” [см.: го]. Эту дату - 30 июля І93І г. - и принято считать датой рождения книжной серии «История Гражданской войны».

Однако замысел серии возник у Горького несколько ранее. В апреле I929 г. он писал инструктору отдела печати ПУРа ${ }^{\mathrm{I}}$ Е.И. Хлебцевичу: «Странно даже как-то обидно знать, что история величайшей гражданской войны все еще не написана и что наша рабоче-крестьянская масса не имеет общего и ясного представления о трагедии, пережитой ею, ее подвигах и трудах, о той цене, которую она заплатила за свою свободу... Я указываю на необходимость создания полной, яркой, вполне доступной пониманию рабоче-крестьянской массы “Истории гражданской войны”... по моему мнению, такую “Историю” отлично могли бы написать... художники слова, конечно, под руководством специалистов истории...» [2, с. 134, I35]. Однако в письме И.В. Сталину от 27 ноября 1929 г. Горький сетует на то, что к его мнению не прислушиваются: «Вот уже два года я настаиваю на необходимости издать для крестьянства “Историю гражданской войны”. История эта крестьянству непонятна, потому что незнакома во всей ее широте. Нужно, чтоб он знал, по каким мотивам рабочий класс начал эту войну, чтобы знал, что рабочие спасли страну от завоевания иностранным капиталом и рабства...»

I Политическое Управление (ПУР) Красной Армии. 
[5, c. I86]. Однако спустя полгода Горький вновь затронул тему издания военно-исторической серии: «Иосиф Виссарионович, с 28 г. я настаиваю на необходимости разработать и издать “Историю гражданской войны” - особенно, - на мой взгляд, необходимую для дела политического, т. е. социалистического воспитания крестьянства» [6, с. 216].

По мнению писателя, книги, посвященные истории Гражданской войны, нужно сделать популярным изданием: «Мне кажется, сделать это надо так: привлечь $\mathrm{P}<\mathrm{eв>воен-совет} \mathrm{и} \mathrm{ПУР,} \mathrm{пускай} \mathrm{избранная} \mathrm{им} \mathrm{комиссия} \mathrm{со-}$ берет весь материал и хронологически организует его. Этот сырой материал должны литературно обработать беллетристы» [5, c. I86-І87].

Одним из главных доказательств необходимости скорейшей работы над созданием серии, по его мнению, было следующее: «Непосредственные участники гражданской войны крестьяне дряхлеют, вымирают, и в их лице мы постепенно теряем живых свидетелей прошлого, людей, которые на своей шкуре испытали давление буржуазии и были активными участниками борьбы с нею... Один знает, что было в Архангельске, другой - дрался в Астрахани, третий - в Одессе, четвертый за Уралом, на Дальнем Востоке, в его уезде, в его селе. Общего же взгляда на гражданскую войну не имеют не только эти свидетели, но даже и многие партийцы, а крестьянской молодежи история гражданской войны или очень плохо, или совершенно не известна» $[6$, с. 216].

Горький считал, что «“История гражданской войны” должна быть написана предельно популярно» [6, с. 2I7]; этому будет способствовать «сырой, фактический материал - т. е. документы» [6, с. 2I7] из архивов Истпарта и Реввоенсовета. И помимо этого серия будет пополняться литературно обработанными «личными воспоминаниями людей, которые активно участвовали в гражданской войне» [6, с. 2I7].

Другим важным условием, выдвигаемым Горьким, было то, что книги серии должны «литературно обработать наши наиболее талантливые литераторы, активные ее участники, непосредственные свидетели и люди, хорошо знающие места действия» [6, с. 217-218].

К этой работе, по мнению писателя, необходимо привлечь писателей, связывая их с регионами страны, о которых они или уже писали, или находятся в процессе работы: по Средней Волге - К.А. Федина, Северному Кавказу и по Гуляй-Полю - А.Н. Толстого, Сибири - В.Я. Зазубри- 
на, А.А. Фадеева, Вс. Иванова, В.Я. Шишкова, Украине - Петро Панча и А. Давидовича, Крыму - А.Г. Малышкина, Петербургу - Ю.Н. Тынянова, Флоту - Ю.Н. Либединского, Б.А. Лавренева, Донбассу - Ю.К. Олешу, по истории казачества - М.А. Шолохова, Одессе и Григорьевщине - И.С. Соколова-Микитова, Архангельску и Мурманску - Л.М. Леонова, Туркменистану - Н.С. Тихонова, басмачам и Афганистану - Л.В. Никулина, Уральским заводам - Артема Веселого, заговорам против Советской республики - О.Д. Форш.

Их задача писателей должна была состоять в том, чтобы «придать “Истории” удобочитаемость, яркость, картинность, - эмоциональную заразительность художественного произведения» [6, с. 2І8].

Настаивая на необходимости этого крупного и важного дела, Горький считал, что «“Историю” надобно посвятить Бойцам Красной Армии и объявить ее обязательной книгой для всех красноармейских библиотек» [6, с. 218].

9 августа г930 г. Постановлением Совета народных комиссаров РСФСР было создано Объединение государственных книжно-журнальных издательств РСФСР (ОГИЗ). 28 августа І930 г. Председатель правления Госиздата А.Б. Халатов обратился к Горькому, сообщая ему: «В осуществление этого постановления у нас сейчас идет большая перестройка всего издательского дела страны. Надо совершенно определенно сказать, что эта работа заполнила все время последних двух месяцев. К І-му октября организационно все крупнейшие издательства будут влиты в Госиздат, а с начала будущего года мы начнем жить по новой схеме. Я глубоко убежден, что этот концерн значительно улучшит все издательское дело...» [7, с. 2І2]. И в этом же письме он обращал внимание писателя на серию «История гражданской войны»: «Вы очень кстати обратились с письмами к намеченным нами редакторам по “Истории гражданской войны”. Соответствующая инстанция полностью утвердила наши предложения - и теперь необходимо взяться серьезно за это дело. Если Вы не будете частенько “нажимать” по этому делу, то я опасаюсь, как бы выполнение этого нужного начинания не слишком затянулось» [7, с. 212].

В ответ на завуалированную просьбу Халатова «нажать», Горький 7 сентября І930 г. обратился в Политбюро: «Разрешите не доказывать необходимость создания и издания популярной “Истории гражданской войны I7-23 гг.” и представить Вашему вниманию, Вашей критике план этой рабо- 
ты <...> Мои соображения как редактора формальной части этой работы, т. е. ее литературной стороны - таковы:

Изложение “Истории гражданской войны” должно быть предельно популярным, вполне доступным пониманию массового читателя, прежде всего - крестьянина. Для этой цели - предельной простоты и ясности языка, красочности, художественности - привлекаются к обработке сырого, документального материала наиболее даровитые литераторы, прямые или косвенные участники гражданской войны.

Нужно сделать книгу, которая, преследуя цель социалистического воспитания массы, была бы интересна и увлекательна для малограмотного взрослого и для юноши. Этого трудно достичь, но это совершенно необходимо и должно быть достигнуто.

Это - первый и крайне ответственный опыт: дать массе рабочих и крестьян яркую, широкую и точную картину недавнего прошлого, в событиях которого непосредственно участвовали десятки тысяч будущих читателей этой книги. Со всею прямотой и суровостью подлинной истории нужно показать массе ее роль в “Гражданской войне” - показать ее героизм, не скрывая, однако, и фактов самопредательства, переходов с красного фронта на белый и т. п., - фактов, которые следует трактовать как явления массового самоубийства и объяснять как уродливое недоразвитие классового самосознания.

Необходимо в каждой области, где бушевала война, выбрать и особенно ярко подчеркнуть несколько пунктов, в которых разрушительная деятельность белых выразилась особенно жестоко и нанесла хозяйству этих пунктов наиболее жестокие удары. Нужно, чтоб население этих пунктов вспомнило все, что им пришлось пережить, претерпеть. Нужно дать цифровые подсчеты убытков, понесенных данным селом, станцией, уездным городом от реквизиции белых банд, от пожаров и грабежей, дать картины насилий и казней. Этим приемом “История” будет особенно глубоко вдвинута в жизнь и с большей силою подействует на развитие самосознания. Материал для таких картин можно обильно черпать из книг участников войны <...> Материал такого рода, т. е. художественно освещенный, у нас не очень обилен, но он убедителен и для массового читателя - очень хороший корм.

С достаточной ясностью нужно показать крестьянству все те случаи, когда оно, предавая рабочих Красной армии, само уничтожало себя, 
шло против своих интересов... Весьма полезны будут и книги участников гражданской войны - бывших красноармейцев, краскомов, политруков. Привлечение к этой работе литераторов будет опытом вовлечения их в серьезную политработу и, можно думать, послужит к пользе нашей литературы»².

В этом письме Горький впервые предложил включить в состав редколлегии серии товарищей М.Н. Покровского, К.Е. Ворошилова, А.С. Бубнова, Я.Б. Гамарника, В.Р. Менжинского или вместо него Г.Г. Ягоду. Основными целями в этой работе этого редакционного совета Горький видел: во-первых, «они проверяют прилагаемый план, вносят в него поправки организационного характера, отводят одних военредакторов, замещают их другими», во-вторых, «берут на себя обязанность проверить весь материал, собранный военредакторами», в-третьих, «назначают редакторов, не показанных в плане, напр., по Закавказью и др.», в-четвертых, «затем они читают весь материал в его окончательно обработанном литературном виде, т. е. готовом для печати»³.

К рекомендациям Горького прислушались и в Постановлении о создании серии «История гражданской войны» был оговорен вопрос о редактировании серии, для чего «образовать: І) Главную редакцию в составе тт. Горького, Молотова, Ворошилова, Кирова, Бубнова, Гамарника и Сталина. 2) Историческую редакцию в составе тт. Покровского, Бубнова, Горького, Ярославского, Скрыпника, Гамарника, Яковлева Я.А., Ахундова, Стецкого, Попова Н.Н. и Эйдемана. 3) Художественную редакцию в составе тт. Горького, Демьяна Бедного, Фадеева, Всеволода Иванова, Леонова, Микитенко, Чарота, Киршона, Эйдемана, Федина, Панферова и М. Кольцова» [го].

Следующим вопросом - весьма важным - для серии было определение объема издания. Первоначальный вариант этого объема был следующий: «Издание, наверное, потребует не меньше І5о листов, разделенных на 6 книг по 25 листов. Эти размеры не должны устрашать нас, мы живем в стране, где расходятся миллионы экземпляров чепуховых книг. Из шести

2 Архив А.М. Горького. ИМЛИ РАН. ПГ-рл-4І-27-3. Письмо М. Горького И.В. Сталину, А.И. Рыкову, М.Н. Покровскому, К.И. Ворошилову, А.С. Бубнову и В.Р. Менжинскому от 7 сентября г930 г.

3 Архив А.М. Горького. ИМЛИ РАН. ПГ-рл-4I-27-3. Письмо М. Горького И.В. Сталину, А.И. Рыкову, М.Н. Покровскому, К.И. Ворошилову, А.С. Бубнову и В.Р. Менжинскому от 7 сентября г930 г. 
томов нужно будет сделать одну книгу для преподавания в школах. Денег на это издание не следует жалеть, оно будет гораздо полезнее любого из “дворцов культуры”, на построение которых, несколько преждевременно, тратятся миллионы. "История гражданской войны” должна быть иллюстрирована материалами “Музея гражданской войны” из “Дома Красной Армии” и снимками с картин художников» [6, с. 2I7].

Вместе с письмом в Политбюро Горький направил Протокол совещания по вопросу об издании «Истории гражданской войны» от 6 августа I930 г. К этому протоколу писатель приклеил листок со своими пояснениями: «Каждому из 7-и томов должна предшествовать вступительная статья, которая дала бы краткий, краеведческого характера, очерк истории, географии, экономики и культуры края. Материал для таких статей можно извлекать из краеведческих сборников, а также из материалов, которые, наверное, имеются в портфеле “Большой Советской энциклопедии”. Эти очерки необходимы для того, чтоб рабочий-уралец имел представление о том, что такое кубанцы, знали, что такое фабрично-заводской Урал, Северный край и т. д., т. е. нужно, чтоб население каждой области знало обо всех других»4.

Однако окончательные планы, характер и тип издания были выработаны в І93I г., когда писатель приехал из Сорренто в Москву. За время его пребывания в СССР прошел ряд заседаний редколлегии серии: 25 мая, I9 июня, Іо августа, 7 сентября г93І г. Два последних заседания прошли под знаком уже опубликованного Постановления ЦК ВКП(б).

На заседании го августа І93І г. было определено количество авторов, редакторов и писателей - всего около г4о человек, из которых $50-$ писатели; тогда же было решено издать брошюрой проспект «Истории гражданской войны», содержание которой было рассчитано на I3 томов. В Архиве А.М. Горького (ИМЛИ) сохранился план издания в I5 т., с пометами Горького, над которым он работал в августе г93г г. Задуманную «Историю Гражданской войны» предполагалось довести до І930-х гг.; последний том должен был быть посвящен политическим процессам, в работе над ним предполагалось участие ОГПУ, между собой члены редакции называли этот том томом заговоров.

4 Архив А.М. Горького. ИМЛИ РАН. ПГ-рл-4I-27-3. Письмо М. Горького И.В. Сталину, А.И. Рыкову, М.Н. Покровскому, К.И. Ворошилову, А.С. Бубнову и В.Р. Менжинскому от 7 сентября г930 г. 
Коллекция эпистолярия М. Горького, хранящаяся в РГАСПИ, открывает новую страницу в исследовании истории книгоиздательской серии «История Гражданской войны». Это - письма главного редактора Горького, направляемые в разные адреса. Именно они показывают весь объем подготовительной работы, структуру механизма, имя которому секретариат редколлегии книжной серии «История гражданской войны».

Вот один из многочисленных примеров. I7 сентября г93І г. главный редактор центральной газеты Узбекистана «Комсомолец Востока» т. Юрасов сообщал в Секретариат Главной редакции серии, что г9 сентября І93I г. будет проведена массовка-встреча ударников Гражданской войны с рабочей молодежью столицы Узбекистана, главной целью которой является «реализация вашего обращения и постановления ЦК партии ${ }^{5}$.

23 сентября І93I г. в газете «Комсомолец Востока» была опубликована приветственная телеграмма, отправленная Секретариатом: «Горячий привет участникам героической борьбы за Советский Узбекистан, рабочей молодежи и всем преданным Советской власти трудящимся Узбекистана. История гражданской войны должна показать самоотверженную борьбу трудящихся национальных республик за советскую власть, за мировую пролетарскую революцию, за социализм. Ударным порядком собирайте материал по истории гражданской войны вашей республики, шлите редакции»7. Приветствие было подписано Горьким 8

В ответном письме 30 сентября І93І г. Юрасов сообщал подробности подготовки и проведения массовки-встречи: «Мобилизуя массы вокруг постановления ЦК ВКП(б), вокруг твоего обращения и твоей телеграммы мы вместе с газетой “Яш-Ленинчи” (Орган ЦК комсомола Узбекистана) провели митинги и вечера на Красновосточном заводе, Ташгэсе, заводе им. Ильича, и ряде других предприятий, на которых выступали рабочие - ударники гражданской войны с воспоминаниями, которые стенографировали и <ко-

\footnotetext{
5 Речь идет о статье М. Горького «Участникам Гражданской войны» и Постановлении ЦК ВКП(б) от зо июля І93г г.

6 РГАСПИ. Ф. 7І. ОП. 36. Д. 9. Л. 89.

7 Комсомолец Востока. 193г. № 133.23 сент.

8 В письме напротив фразы по левому полю запись: «Она <т. е. встреча. - О.Б.> приняла характер большой демонстрации, огромнейшего желания выполнение решение ЦК ВКП(б), выполнить твои указания, данные нам в телеграмме» рукой, предположительно заведующего редакцией И.М. Данилова, была сделана запись: «Телеграмму готовил Данилов, подписывал А. М.» [РГАСПИ. Д. 7І. ОП. 36. Д. 9. Л. 88].
} 
торые > послужат материалом для истории <...> Массовка состоялась 26 сентября. В ней участвовало ок. I5 тыс. рабочих, комсомольцев Ташкента»9.

Юрасов также сообщал, что все выступления были застенографированы и высылаются вместе с рядом других материалов, о том «как наша комсомольская газета вела подготовку к этой массовке, организовывала трудящихся... $>^{\text {10}}$. Вместе с ними в адрес редакции были отправлены документы по истории гражданской войны в Туркестане, поскольку «в материалах, которые описывают Гражданскую войну в Средней Азии, имеется много неверностей» ${ }^{\text {II }}$

Горький привлек к работе над «Историей Гражданской войны» не только писателей, но и военспецов, таких как, например, начальник вооружений РККА М.Н. Тухачевский, которому писал 26 января I934 г.: «Дорогой товарищ! К сожалению, Вы все еще остались в стороне от работ над “Историей гражданской войны”, а мы уже развернули работу над III томом.

Очень прошу Вас взять на себя разработку одной из глав по III тому, именно: “Военное положение республики к октябрю г918 года”. Всю подготовительную работу - подбор материалов, систематизация их и т. д. мы берем на себя. На Вашу долю выпадет только редактирование и окончательное оформление главы.

Прошу Вас поговорить о подробностях работы с тов. Минцем. Думаю, что выпустить “Историю гражданской войны” без одного из активных участников, каковым являетесь Вы ${ }^{\mathrm{I} 2}$, будет неловко.

Крепко жму руку»³.

Письма Горького, в которых речь идет о подготовке первого тома серии или его упоминание, поражают «разбросанностью» адресатов. Как опытный редактор, он был в курсе абсолютно всех проблем, связанных с изданием будущей книги.

Вот письмо от го февраля І934 г., отправленное в Культпроп А.И. Стецкому: «Дорогой товарищ!

9 РГАСПИ. Ф. 7г. Оп. 36. Д. 9. Л. 87-87 об.

го Там же.

II Там же.

I2 М.Н. Тухачевский в годы Гражданской войны командовал армиями на Восточном и Южном фронтах; был командующим Кавказским фронтом.

I3 РГАСПИ. Ф. 7І. ОП. 36. Д. ІІ. Л. 5г. 
Мы с Вами уже говорили о первом томе “Истории гражданской войны”. За исключением главы товарища Радека весь первый том готов. Я очень прошу Вас в ближайшие дни дать окончательный текст своей главы. Надо принять во внимание, что главу придется еще редактировать. Все это может затянуть и без того запоздавший выход первого тома.

Надеюсь сразу после съезда иметь Вашу работу» ${ }^{\Upsilon 4}$.

В этот же день Горький отправил письмо члену редколлегии «Правды» К.Б. Радеку: «Вы мне обещали сразу после съезда представить свою главу по первому тому “Истории гражданской войны”. Весь том у нас готов, но я, к сожалению, не могу приступить к редактированию тома без Вашей главы. Все сроки, Вами лично намеченные, давно прошли.

$75 \%$ съезда $^{15}$, по докладу мандатной комиссии, участники гражданской войны. Многие из них с большим недоумением спрашивали, где же история? Почему она не выходит? Неужели нам придется сообщить, что в задержке виноват, в частности, тов. Радек?

Думаю, все же что в ближайшие дни Ваша глава к нам поступит. Не сомневаюсь, что задержка во времени будет компенсирована содержанием главы. Большой привет. Всего доброго. В ожидании главы» ${ }^{16}$.

В конце февраля I934 г. первый том был готов и его должны были отправить в производство. Однако возникли сложности, и для их разрешения Горький обратился к члену ЦИК СССР А.С. Енукидзе: «Уважаемый тов. Енукидзе! В свое время я обращался к Вам с просьбой об оказании помощи в издании серии “Истории гражданской войны”.

Ваша техчасть высказалась против приема I-го тома в производство, основываясь на неподготовленности Вашей типографии к этому изданию. Несмотря на это, я убедительно прошу Вас дать распоряжение об изготовлении одной полосы набора шрифтом “четкий”, который очень понравился Главной редакции и тиснуть 20 экз. на хорошей бумаге.

Я надеюсь, что Вы не откажете в дальнейшем представить этот шрифт для набора всей серии» ${ }^{17}$.

I4 РГАСПИ. Ф. 7І. ОП. 36. Д. ІІ. Л. 57.

I5 Речь идет о XVII съезде Всесоюзной Коммунистической партии (б), который проходил

в Москве с 26 января по го февраля г934 г.

І6 РГАСПИ. Ф. 7І. ОП. 36. Д. ІІ. Л. 55.

I7 РГАСПИ. Ф. 7І. ОП. 36. Д. гІ. Л. 6I. 
Первый том «Истории гражданской войны» был готов к лету 1934 г., для печати была избрана Ленинградская типография «Печатный двор». Горький обратился к председателю Союза печатников тов. Магидову II июля 1934 г. с просьбой: «Вы обещали тов. Минцу помочь нам, как только мы закончим работу над I-м томом “Истории гражданской войны”.

Том готов, завтра мы посылаем его в типографию "Печатный двор" и я очень просил бы Вас сказать ленинградским печатникам, что и в техническом отношении история гражданской войны должна быть достойна нашего времени» ${ }^{18}$.

Первый том вышел тиражом 300000 экз. в І935 г. [см.: 9]; второе издание вышло тиражом 500000 экз. в 1936 г. [см.: го] после смерти писателя.

Подводя итоги работы Горького над серией «История гражданской войны», стоит отметить, что замысел Горького не смог воплотиться в задуманном объеме.

Вторая книга серии вышла в г943 г. [см.: г]. Несмотря на то что фамилия Горького еще была среди редакторов тома, было ясно, что серия претерпевает серьезные изменения, что, кстати, и было подтверждено выходом следующих томов: в 1958 г. тиражом 50000 экз. вышел 3-й том [см.: II], в І959 г. - тиражом 40000 экз. - 4-й том [см.: І2], в І96о г. тиражом 30000 экз. - 5-й том [см.: 13]. Вот так закончилась история задуманной М. Горьким книгоиздательской серии в I5 томах. 


\section{Список литературы}

I Великая пролетарская революция (Октябрь - ноябрь I9I7 года) / под ред. М. Горького, В. Молотова, К. Ворошилова, С. Кирова, А. Жданова, И. Сталина; сост. тома: Г.Ф. Александров, И.И. Минц, П.Н. Поспелов, Ем. Ярославский, Э.Б. Генкина, Е.Н. Городецкий, И.М. Разгон, И.П. Товстуха. М.: Гос. изд-во полит. лит., І 943.656 c. Горький М. Собр. соч.: в 30 т. М.: ГИХЛ, г956. Т. зо: Письма, телеграммы, надписи. 1927-1936. 8г9 с. Горький М. Участникам Гражданской войны // Известия. І93І. № 209. 3І июля. C. 2.

4 Горький М. Участникам Гражданской войны // Правда. І93І. № 209. 3І июля. С. 2. 5 Из переписки А.М. Горького / публ. 3. Черновой, 3. Тихоновой // Известия ЦК КПСС. I989. № 3. С. I8I-I88.

6 Из переписки А.М. Горького / публ. З. Черновой, С. Заики, Л. Спиридоновой, 3. Тихоновой // Известия ЦК КПСС. 1989. № 7. С. 21І-220.

7 М. Горький и советская печать / архив А.М. Горького; редколлегия: А.Г. Дементьев, С.С. Зимина, И.С. Черноуцан, Р.П. Пантелеева. М.: Наука, І964. Т. Х. Кн. І. $4 \mathrm{I} 5 \mathrm{C}$.

8 Подготовка великой пролетарской революции. (От начала войны до начала октября І9г7 г.) / под ред. М. Горького, В. Молотова, К. Ворошилова, С. Кирова, А. Жданова, А. Бубнова, Я. Гамарника, И. Сталина; сост. тома: Я.Л. Берман, В.А. Быстрянский, М. Горький, С.М. Диманштейн, Я.Г. Долецкий, Л.Н. Крицман, Н.В. Крыленко, М.И. Кубанин, Д.З. Мануильский, И.И. Минц, В.П. Милютин, О.А. Пятницкий, Ф.Ф. Раскольников, А.И. Стецкий, Б.М. Таль, И.П. Товстуха, А.И. Угаров, Н.П. Эйдеман. М.: Огиз (Государственное издательство «История гражданской войны»), І935.350 с.

9 Подготовка великой пролетарской революции. (От начала войны до начала октября І9І7 г.). 2-е изд.; под ред. М. Горького, В. Молотова, К. Ворошилова, С. Кирова, А. Жданова, А. Бубнова, Я. Гамарника, И. Сталина; сост. тома: Я.Л. Берман, В.А. Быстрянский, М. Горький, С.М. Диманштейн, Я.Г. Долецкий, Л.Н. Крицман, Н.В. Крыленко, М.И. Кубанин, Д.З. Мануильский, И.И. Минц, В.П. Милютин, О.А. Пятницкий, Ф.Ф. Раскольников, А.И. Стецкий, Б.М. Таль, И.П. Товстуха, А.И. Угаров, Н.П. Эйдеман. М.: Огиз, г936. 350 с. Постановление ЦК ВКП(б) «Об издании “Истории гражданской войны” // Правда. І93г. № 209. 3І июля. С. 3.

II [История гражданской войны. Т. 3]. Упрочение советской власти. Начало иностранной военной интервенции и гражданской войны. (Ноябрь I9I7 г. - март I9I9 г.) / ред. комиссия тома: С.Ф. Найда, Г.Д. Обичкин, Ю.П. Петров, А.А. Стручков, Н.И. Шатагин. М.: Гос. изд-во полит. лит., І958. 678 с. 
I2 [История Гражданской войны. Т. 4]. Решающие победы Красной Армии над объединенными силами Антанты и внутренней контрреволюции (март I9I9 г. - февраль 1920 г.) / ред. комиссия тома: С.Ф. Найда, Г.Д. Обичкин, Ю.П. Петров, А.А. Стручков, Н.И. Шатагин, С.Н. Шишкин. М.: Гос. изд-во полит. лит., І959. 444 c.

I3 [История гражданской войны. Т. 5]. Конец иностранной военной интервенции и гражданской войны в СССР. Ликвидация последних очагов контрреволюции. (Февраль І920 г. - октябрь І922 г.) / ред. комиссия тома: С.М. Будённый, С.Ф. Найда, Г.Д. Обичкин, Н.Г. Софинов, А.А. Стручков, Н.И. Шатагин. М.: Гос. изд-во полит. лит., І960. 420 с. 


\section{References}

I Velikaya proletarskaya revolyuciya (Oktyabr - noyabr I9I7 goda) [The great proletarian revolution (October - November I9I7)], eds. M. Gorky, V. Molotov, K. Voroshilov, S. Kirov, A. Zhdanov, I. Stalin; the volume was prepared by: G.F. Aleksandrov, I.I. Mincz, P.N. Pospelov, Em. Yaroslavskiy, E.B. Genkina, E.N. Gorodeczkiy, I.M. Razgon, I.P. Tovstukha. Moscow, Gosudarstvennoe izdatelstvo politicheskoy literatury Publ., I943. 656 p. (In Russ.) Gorkiy M. Sobranie sochineniy: $v$ o t. [Gorky M. Works: in 30 vols.]. Moscow, GIKhL Publ., I956. Vol. 30: Pisma, telegrammy, nadpisi [Letters, telegrams, inscriptions]. I927-I936. 8I9 p. (In Russ.)

3 Gorkiy M. Uchastnikam Grazhdanskoy voyny [Participants in the civil war]. Izvestiya, I93I, no 209, July 3I, p. 2. (In Russ.)

4 Gorkiy M. Uchastnikam Grazhdanskoy voyny [Participants in the civil war]. Pravda, I93I, no 209, July 3I, p. 2. (In Russ.)

5 Iz perepiski A.M. Gorkogo [From A.M. Gorky’s correspondence], publ. Z. Chernovoy, Z. Tikhonovoy. Izvestiya CzK KPSS, I989, no 3, pp. I8I-I88. (In Russ.) Iz perepiski A.M. Gorkogo [From A.M. Gorky’s correspondence], publ. Z. Chernovoy, S. Zaiki, L. Spiridonovoy, Z. Tikhonovoy. Izvestiya CzK KPSS, I989, no 7, pp. 2II-220. (In Russ.)

$7 \quad$ M. Gorkiy i sovetskaya pechat [M. Gorky and the Soviet press], arkhiv A.M. Gorkogo [A.M. Gorky archive]; editorial board: A.G. Dementev, S.S. Zimina, I.S. Chernouczan, R.P. Panteleeva. Moscow, Nauka Publ., I964. Vol. X. Book. I. 4I5 p. (In Russ.) Podgotovka velikoy proletarskoy revolyucii. (Ot nachala voyny do nachala oktyabrya I9I7 g.) [Preparation of the Great Proletarian revolution. (From the beginning of the war until the beginning of October I9I7)], eds: M. Gorky, V. Molotov, K. Voroshilov, S. Kirov, A. Zhdanov, A. Bubnov, Ya. Gamarnik, I. Stalin; the volume was prepared by: Ya.L. Berman, V.A. Bystryanskiy, M. Gorkiy, S.M. Dimanshteyn, Ya.G. Doleczkiy, L.N. Kriczman, N.V. Krylenko, M.I. Kubanin, D.Z. Manuilskiy, I.I. Mincz, V.P. Milyutin, O.A. Pyatniczkiy, F.F. Raskolnikov, A.I. Steczkiy, B.M. Tal, I.P. Tovstukha, A.I. Ugarov, N.P. Eydeman. Moscow, Ogiz (Gosudarstvennoe izdatelstvo "Istoriya grazhdanskoy voyny") Publ., I935. 350 p. (In Russ.) Podgotovka velikoy proletarskoy revolyucii. (Ot nachala voyny do nachala oktyabrya I9I7 g.) [Preparation of the Great Proletarian revolution. (From the beginning of the war until the beginning of October I9I7)], 2-nd ed., eds. M. Gorky, V. Molotov, K. Voroshilov, S. Kirov, A. Zhdanov, A. Bubnov, Ya. Gamarnik, I. Stalin; the volume is prepared by: Ya.L. Berman, V.A. Bystryanskiy, M. Gorky, S.M. Dimanshteyn, Ya.G. Doleczkiy, L.N. Kriczman, N.V. Krylenko, M.I. Kubanin, D.Z. Manuilskiy, I.I. Mincz, V.P. Milyutin, O.A. Pyatniczkiy, F.F. Raskolnikov, A.I. Steczkiy, B.M. Tal, I.P. Tovstukha, A.I. Ugarov, N.P. Eydeman. Moscow, Ogiz Publ., I936. 35 p. (In Russ.) 
Io Postanovlenie CzK VKP(b) "Ob izdanii 'Istorii grazhdanskoy voyny”” [The resolution of the Central Committee of the CPSU(b) "On the Publication of The History of the Civil War”]. Pravda, I93I, no 209, July 3I, p. 3. (In Russ.)

II [The History of the Civil War, vol. 3]. Uprochenie sovetskoy vlasti. Nachalo inostrannoy voennoy intervencii i grazhdanskoy voyny. (Noyabr I9I7g. - mart I9I9g.) [The consolidation of the Soviet power. Beginning of the foreign military intervention and of the Civil War. (November I9I7 - March I9I9)], editorial board: S.F. Nayda, G.D. Obichkin, Yu.P. Petrov, A.A. Struchkov, N.I. Shatagin. Moscow, Gosudarstvennoe izdatelstvo politicheskoy literatury Publ., I958. 678 p. (In Russ.)

I2 [The History of the Civil War, vol. 4]. Reshayuschie pobedy Krasnoy Armii nad obedinennymi silami Antanty i vnutrenney kontrrevolyucii (mart I9I9g. - fevral I920 g.) [Red Army decisive victories over the combined forces of the Entante and of the internal counterrevolution. (March I9I9 - February I920)], editorial board: S.F. Nayda, G.D. Obichkin, Yu.P. Petrov, A.A. Struchkov, N.I. Shatagin, S.N. Shishkin. Moscow, Gosudarstvennoe izdatelstvo politicheskoy literatury Publ., I959. 444 p. (In Russ.)

I3 [The History of the Civil War, vol. 5]. Konecz inostrannoy voennoy intervencii $i$ grazhdanskoy voyny $v$ SSSR. Likvidaciya poslednikh ochagov kontrrevolyucii. (Fevral I920 g. - oktyabr 1922 g.) [An end to foreign military intervention and civil war in the USSR. The elimination of the last pockets of counter-revolution. (February I920 - October I922)], editorial board: S.M. Budyonnyy, S.F. Nayda, G.D. Obichkin, N.G. Sofinov, A.A. Struchkov, N.I. Shatagin. Moscow, Gosudarstvennoe izdatelstvo politicheskoy literatury Publ., I960. 420 p. (In Russ.) 